Communication

\title{
In Search of High-Yielding and Single-Compound-Yielding Plants: New Sources of Pharmaceutically Important Saponins from the Primulaceae Family
}

\author{
Maciej Włodarczyk ${ }^{1, *} \oplus^{\infty}$, Paweł Pasikowski ${ }^{2}{ }^{\oplus}$, Kinga Osiewała ${ }^{3}$, Aleksandra Frankiewicz $^{3}$, \\ Andrzej Dryśs ${ }^{4}$ (i) and Michał Gleńsk ${ }^{1}$ (i) \\ 1 Department of Pharmacognosy and Herbal Drugs, Wroclaw Medical University, Borowska 211 A, \\ 50-556 Wrocław, Poland \\ 2 Mass Spectrometry Laboratory, Polish Center for Technology Development, Stabłowicka 147, \\ 54-066 Wrocław, Poland \\ 3 Students Scientific Cooperation on Pharmacognosy, Wroclaw Medical University, Borowska 211 A, \\ 50-556 Wrocław, Poland \\ 4 Department of Physical Chemistry and Biophysics, Wroclaw Medical University, Borowska 211 A, \\ 50-556 Wrocław, Poland \\ * Correspondence: maciej.wlodarczyk@umed.wroc.pl; Tel.: +48-71-78-40-223
}

Received: 30 December 2019; Accepted: 25 February 2020; Published: 29 February 2020

\begin{abstract}
So far, only a few primrose species have been analyzed regarding their saponin composition and content. Moreover, the roots of only two of them are defined by the European Union (EU) Pharmacopoeia monograph and commercially utilized by the pharmaceutical industry. Thus, this study intended to find some new sources of main triterpene saponins from Primulae radix, namely primulasaponins I and II together with the closely related sakurasosaponin. Using isolated standards, UHPLC-ESI-HRMS served to assess over 155 Primulaceae members qualitatively and quantitatively. Nine examples of plants accumulating over $5 \%$ of primulasaponin I in their roots were found. Among them, in one case, it was found as the almost sole secondary metabolite with the concentration of 15-20\% (Primula grandis L.). A reasonable content of primulasaponin II was found to be typical for Primula vulgaris Huds. and P. megaseifolia Boiss. \& Bal. The sakurasosaponin level was found in seven species to exceed $5 \%$. The finding of new, single and rich sources of the abovementioned biomolecules among species that were never analyzed phytochemically is important for future research and economic benefit. The chemotaxonomic significance of the occurrence of these three saponins in Primulaceae is discussed.
\end{abstract}

Keywords: primrose root; Primulae radix; primulasaponin; sakurasosaponin; 13,28-epoxyoleanane saponins; Primula; Dodecatheon; Auganthus; biodiversity

\section{Introduction}

Primulaceae Batsch. is a large family covering many perennial and herbaceous plants. Members of this family are widely distributed in the Northern Hemisphere, particularly in the meadows and rocky valleys of the Alps, Apennines, Pyrenees, Himalayas and North American Cordillera but also in dry regions of Kazakhstan, Iran and Turkey. Today, some of the primroses are known exclusively from herbaria specimens while several exist as endangered endemics. Since the time of Charles Darwin and A. K. Bulley, primulaceous plants have been a point of interest for botanists and alpine enthusiasts as well as for the gardeners who help to maintain threatened species and discover new ones [1-5]. 
Thanks to them, over 200 Primulaceae-related species remain in the plant trade apart from decorative varieties. Due to these and the fact that most Primula species possess partly recognized chemical composition [6-8], they provide an interesting field for phytochemical research.

According to the European Pharmacopoeia, the official primrose root (Primulae radix) may be obtained from Primula veris L. or P. elatior (L.) Hill. and is well known as an efficient secretolytic and expectorant drug [9-11]. It was widely introduced to European academic medicine as a surrogate of the American Senega root during WWI. It is still popular as a component of simple and complex pharmaceutical formulations [9]. It has been proven that the main saponins and active components of the official drug are primulasaponins: I (=primulasaponin A, PSI) and II (PSII), sometimes mentioned as primula acids due to the acidic character of their glycone part $[9,12]$.

Primula sieboldii E. Morren is common in the Far East region (Japan, Amurland, Manchuria and Korea). The phytochemical value of this plant is connected with the triterpenoid biosynthesis yielding almost a single saponin, sakurasosaponin (SSI) [13], a close structural relative of PSI and PSII (Figure 1). However, ethnomedicinal applications of P. sieboldii to treat cough and bronchitis are not widely known [14].

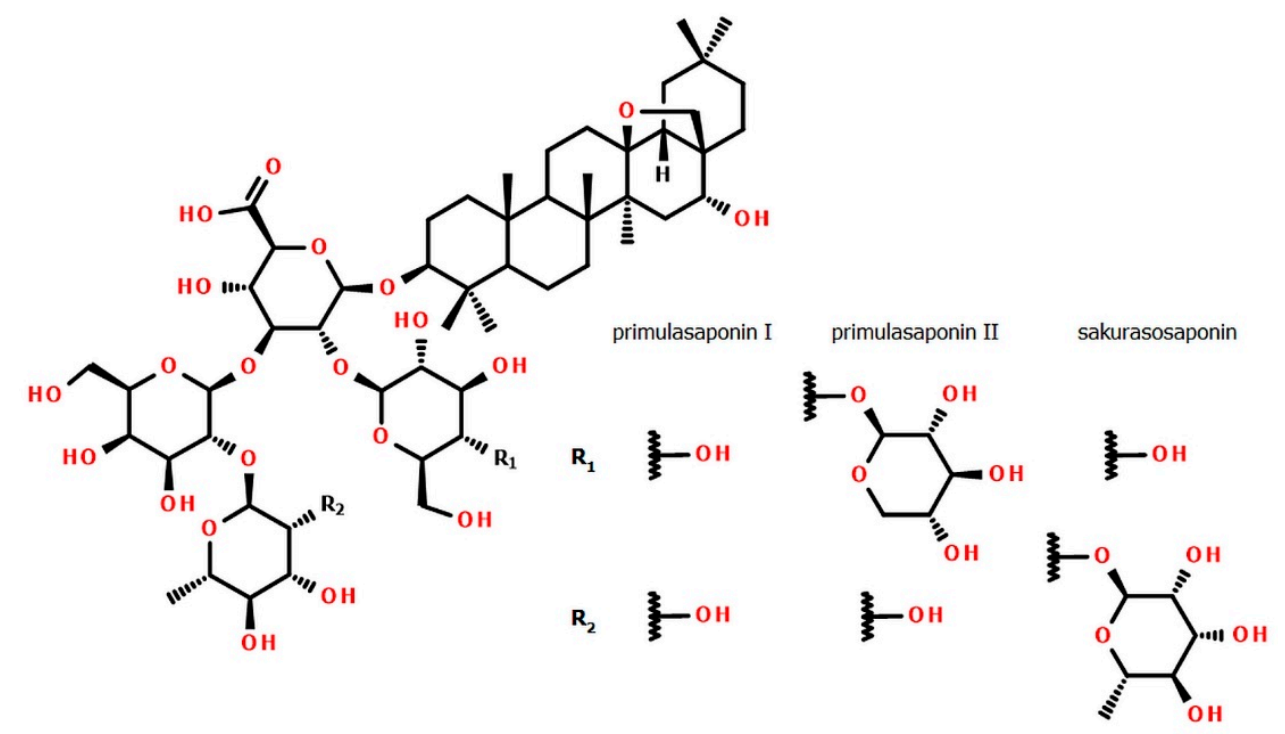

Figure 1. Structures of primulasaponins I, II and sakurasosaponin (PSI, PSII and SSI, respectively).

Besides the well-known activities of saponins such as expectorant or vasoprotectant, an increasing number of researchers are interested in the evaluation of their promising positive interactions with, for example, chemotherapeutics [15-17]. Their usage in pharmacy, cosmetology and the food industry as natural and efficient emulsifiers or foaming agents is also desirable [18-20].

The glycosides and glycoside-esters of oleanane type are among the most widely distributed groups of saponins. Despite their wide occurrence, primulasaponins I, II and sakurasosaponin were previously not the object of any clinical study. However, they belong to 13,28-epoxyoleanane saponins that are of particular medical interest. Epoxidized oleanane derivatives were found to be active as enzyme inhibitors [21], anti-mycobacterial and anti-protozoan compounds [22,23] and selectively cytotoxic molecules $[24,25]$. It was demonstrated that the partially deglycosylated metabolites of long-chain 13,28-epoxyoleanane saponins also display antitumor activities at a level similar to their prodrug digested by intestinal flora [26].

Primulasaponins I and II, as well as sakurasosaponin, may serve as a readily available model compound for research (including structural modifications) in the mentioned areas of medicine. Particularly interesting are aldehydes such as ardisiacrispin B that can display, for example, cytotoxic effects in multi-factorial drug-resistant cancer cells [25,27]. The researchers know that the problem of the unavailability of large amounts of a single specialized metabolite is usually a hurdle in semi-synthesis. 
The number of unwanted by-products increases dramatically with a decrease in the purity of the substrate. Herewith, the use of single-metabolite yielding plants could be a strategy to work around this problem.

High-yielding sources of specialized natural compounds are not very frequent. The primary phytochemical education teaches that such compounds are usually found in concentrations that do not exceed $3-5 \%$ of the dry mass of plant material. Positive exceptions include quinine ( $>10 \%$ [28]) and some new sources of theobromine ( $>6 \%$, Camelia ptilophylla [29]). Among phenylpropanoids, eugenol reaches $10-12 \%$ in cloves (at the level of $>80 \%$ in essential oil). The highest yielding non-alkaloid substances usually occur in plants as complex mixtures (e.g., $10 \%$ of tannins mixture in oak galls, $\sim 6 \%$ of saponins mixture in horse-chestnut seeds). The LC-MS proven concentrations of single saponins in the Primulaceae family are usually about $2-6 \%[7,30]$.

The pharmaceutical industry prefers single, pure and well-defined biomolecules to serve as the standards. The most readily available compounds or the most active ones are used for the quality determination of raw herbal drugs as well as the reference for clinical studies. Single compounds can be conveniently evaluated, packed and dosed. On the other hand, the purification of natural compounds is usually bothersome and expensive, especially in the complex group of saponins. The lack of broad introduction of modern and rapid strategies for saponins' determination results in perpetuating semi-quantitative, non-selective methods based on measurements of simple physicochemical properties (e.g., the new monograph included in European Pharmacopoeia (2.8.24) describes the "foam test" to evaluate the quality of saponin drugs [31]).

The objective of this study was to evaluate the distribution and average concentrations of the abovementioned saponins in commercially available Primulaceae species by the use of a cost-effective UHPLC-HRMS method [32]. The second target of this study was to find any species producing the main active compounds in significant quantities preferably as sole substances. The final goal was to identify primulas that could be further used as substitutes for cowslip and oxlip in medical use or utilized as a raw material to efficiently produce significant quantities of selected saponin compounds for commercial purposes or pharmacological deep-research needs.

\section{Materials and Methods}

\subsection{Chemicals}

LC-MS grade solvents were purchased from Merck (Darmstadt, Germany) and Sigma-Aldrich (St. Louis, MO, USA) while those of analytical grade were from Chempur (Piekary Ślaskie, Poland) and POCh (Lublin, Poland).

\subsection{Plant Material}

The roots of the Primulaceae representatives were obtained from various botanical collections and nurseries. A total amount of 157 taxa were gathered. Of 111 Primula species and varieties, 60 belonged to Aleuritia, 11 to Auganthus, 30 to Auriculastrum and 10 to Primula subgenera. Additionally, the following primrose relatives were collected: 24 Androsace members together with 5 Cortusa, 2 Dionysia, 2 Hottonia, 2 Lysimachia, 2 Omphalogramma, 6 Soldanella and 3 Vitaliana taxa. Some were repeated in consecutive years. Plants were authenticated $[1-4,33]$ and documented by photography by the author (M.W.). The plants were harvested in the late summer stage of growth except for lysimachias and hottonias (spring/summer). As a comparison, four trade samples of primrose root deposited in the collection of the Department of Pharmacognosy and Herbal Drugs were used.

The roots were carefully washed, separated from rhizomes and leaves and dried at room temperature in the shade. Vouchers of plant substances were deposited in the Department of Pharmacognosy and Herbal Drugs of Wroclaw Medical University. The precise list of all plant samples and their origin (donators) is combined in Appendix A Table A1. 


\subsection{Preparation of Samples}

For HPLC evaluation, each sample was precisely weighed (100 mg), transferred into a sealed vial and extracted with $2 \mathrm{~mL}$ of $70 \% \mathrm{MeOH}$ for 15 minutes in an ultrasonic bath (Bandelin, Berlin, Germany) at $25{ }^{\circ} \mathrm{C}$ and $50 \%$ of the power. $1 \mathrm{~mL}$ of each extract was filtered using $0.22 \mu \mathrm{m}$ PTFE single-use syringe filters (Merck-Millipore, Darmstadt, Germany), diluted 100 times with acetonitrile/water mixture (1/1, v/v; LC-MS class) and stored at $4{ }^{\circ} \mathrm{C}$ before analysis [32].

\subsection{Preparation of Standards}

The standards of primulasaponin I and II were isolated from the commercial primrose root (complies with Pharmacopoeia requirements; Galke GmbH, Gittelde, Germany). The procedure was as follows: $50 \mathrm{~g}$ of the root was homogenized (A11; IKA, Königswinter, Germany) and extracted twice with $0.5 \mathrm{~L}$ of $70 \%$ methanol. The resulting extract was concentrated using a rotary evaporator (Büchi, Flawil, Switzerland) at $40{ }^{\circ} \mathrm{C}$, diluted with water, applied on a Diaion HP-20 SPE column (Sigma-Aldrich, St. Louis, MO, USA) and eluted with water/methanol of an increasing gradient. Fractions eluted with $50 \% \mathrm{MeOH}$, containing a mixture of saponins (702 mg; $1.4 \%$ of starting material), were combined, concentrated and subjected to LC on silica (Merck, Darmstadt, Germany) in ethyl acetate/acetic acid/water $(5 / 1 / 1, v / v / v)$ as the mobile phase [16]. Later, the eluates were collected according to their TLC profiles. For TLC analysis, the same solvent system was used as for LC on silica. Finally, the combined eluates were purified by solid-phase extraction (SPE) on the Chromabond C18 column (Macherey-Nagel, Düren, Germany) giving as a result pure saponins PSI (33 mg) and PSII (73 mg).

The standard of sakurasosaponin was isolated from commercial P. sieboldii roots (Kevock Garden, Lasswade, UK). $1.60 \mathrm{~g}$ of the powdered root was extracted by 1 -day maceration with $70 \%$ methanol. The extract was diluted with water and subjected to SPE on the Chromabond C18 column. The fraction eluted with 70\% methanol was collected, evaporated to dryness (60 mg) and finally purified by preparative TLC on an RP-18 W plate (Macherey-Nagel, Düren, Germany), giving as a result 25 mg of SSI.

The saponins were stored as powders at $4{ }^{\circ} \mathrm{C}$ before the NMR and HRMS analysis. An aliquot of isolated saponins was then subjected to HRMS, ${ }^{1} \mathrm{H}$ - and ${ }^{13} \mathrm{C}$ NMR spectroscopy, including $2 \mathrm{D}$ experiments and compared positively against assignments from the literature [12,13].

The stock solutions containing $2.0 \mathrm{mg} / \mathrm{mL}, 2.4 \mathrm{mg} / \mathrm{mL}$ and $2.2 \mathrm{mg} / \mathrm{mL}$ of PSI, PSII and SSI respectively were prepared in acetonitrile/water $(1 / 1, v / v)$ and stored at $4{ }^{\circ} \mathrm{C}$ before the analytical use.

\subsection{General NMR and HRMS Experimental Procedures}

${ }^{1} \mathrm{H},{ }^{13} \mathrm{C}$ and 2D NMR spectra were obtained on a Bruker Avance 300 NMR spectrometer (Bruker BioSpin, Rheinstetten, Germany), operating at $300 \mathrm{MHz}$ and $75 \mathrm{MHz}$ respectively at $300 \mathrm{~K}$, using standard pulse programs and methanol-d4 (Armar AR, Döttingen, Switzerland) as well as DMSO- $d 6$ (Armar AR) as the solvent. HRMS measurements of isolated compounds were conducted on the ESI-qTOF Maxis instrument (Bruker Daltonics, Bremen, Germany) while for UHPLC-HRMS detection ESI-qTOF Compact (Bruker Daltonics) was used. The instruments were operated in negative mode and calibrated with the Tunemix mixture (Bruker Daltonics) with $\mathrm{m} / z$ standard deviation below $0.5 \mathrm{ppm}$. In the case of the UHPLC-MS measurements a calibration segment was introduced at the beginning of every single run. The mass accuracy of saponin standards was within $3 \mathrm{ppm}$. The analysis of the obtained mass spectra was carried out using Data Analysis and Quant Analysis (Bruker Daltonics) software. The main instrumental parameters were as follows: scan range 50-2200 m/z, nebulizer pressure 1.5 bar, dry gas $\left(\mathrm{N}_{2}\right) 7.0 \mathrm{~L} / \mathrm{min}$, temperature $200{ }^{\circ} \mathrm{C}$, capillary voltage $2.2 \mathrm{kV}$, ion energy $5 \mathrm{eV}$, collision energy $10 \mathrm{eV}$, low mass set at $200 \mathrm{~m} / \mathrm{z}$. The samples were dissolved in acetonitrile/water (1:1, $v / v$ ) containing $0.1 \% \mathrm{HCOOH}$. 


\subsection{Purity of Standards}

The purity of isolated standards of saponins was ascertained using a ${ }^{1} \mathrm{H}-\mathrm{qNMR}$ method with maleic acid (Fluka, Buchs, Switzerland) as the internal standard with declared $99.94 \%$ content. Precisely weighed samples of each saponin were mixed with the precisely weighed standard and dissolved in $1 \mathrm{~mL}$ of methanol- $d 4$ (Armar AR) in two repetitions. $600 \mu \mathrm{L}$ of each was used for analysis in a 5 $\mathrm{mm}$ tube on $700 \mathrm{MHz}$ Bruker apparatus equipped with TXI CP (Bruker BioSpin). The analysis was conducted according to the procedure of the Polish Center for Technology Development, based on [34].

\subsection{LC-MS Analytical Conditions}

The Thermo Scientific UHPLC Ultimate 3000 apparatus (Thermo Fisher Scientific, Waltham, MA, USA) consisted of an LPG-3400RS quaternary pump with a vacuum degasser, a WPS-3000RS autosampler and a TCC-3000SD column oven. The ESI-qTOF Compact (Bruker Daltonics, Bremen, Germany) was connected as the MS detector. The separation was achieved on a Kinetex C-18 column $(150 \times 2.1 \mathrm{~mm})$ of $2.6 \mu \mathrm{m}$ particle size, core-shell type (Phenomenex, Torrance, CA, USA). The gradient elution system consisted of $0.1 \% \mathrm{HCOOH}$ in water (mobile phase A) and $0.1 \% \mathrm{HCOOH}$ in acetonitrile (mobile phase B). At the flow rate of $0.3 \mathrm{~mL} / \mathrm{min}$, the following elution program was used: $0 \rightarrow 1$ $\min (2 \% \rightarrow 30 \% \mathrm{~B}), 1 \rightarrow 31 \mathrm{~min}(30 \% \rightarrow 60 \% \mathrm{~B}), 31 \rightarrow 31.5 \mathrm{~min}(60 \% \rightarrow 100 \% \mathrm{~B}), 31.5 \rightarrow 35.5 \mathrm{~min}(100 \% \mathrm{~B})$. The column was equilibrated for $7 \mathrm{~min}$ before the next analysis. Blanks were added after each run to avoid any sample carryover. All analyses were carried out isothermally at $30{ }^{\circ} \mathrm{C}$. The injection volume for samples and standard solutions was $5 \mu \mathrm{l}$. Each analysis was calibrated in the first segment of analysis and performed in duplicate. The method was as in Reference [32].

\subsection{Validation of the Analytical Method}

The UHPLC-MS assay was validated with respect to the specificity, linearity, precision, accuracy and stability.

\subsubsection{Specificity}

Concentrations of the saponins were calculated using areas of peaks from EIC chromatograms extracted for $1103.564 \pm 0.01 \mathrm{~m} / \mathrm{z}$ (PSI, $15.67 \mathrm{~min} \pm 0.50 \mathrm{~min}), 1235.606 \pm 0.01 \mathrm{~m} / \mathrm{z}$ (PSII, $14.07 \mathrm{~min} \pm$ $0.50 \mathrm{~min}$ ) and for $1249.622 \pm 0.01 \mathrm{~m} / \mathrm{z}$ (SSI, $15.10 \mathrm{~min} \pm 0.50 \mathrm{~min})$. The concentrations were measured in triplicate. Each sample was evaluated manually for the absence of closely eluting interferences (within \pm 0.50 min of the nominal retention time) using the abovementioned extraction and UHPLC-MS conditions. Because every taxon possessed different patterns of interfering compounds, validation parameters were analyzed using standards.

\subsubsection{Linearity, Range and Limits of Analysis}

The linearity was achieved by assaying a series of the mixed standard solution (PS I, PS II, SSI; consisting of 20 analytic points for each analyte; in a range of $0.050-250 \mu \mathrm{g} / \mathrm{mL}$ ) in duplicate over three consecutive days. The efficient calibration equation to assure the calibration curve fit in the whole range of detector response as well as to include different saponin content in samples was proposed to be:

$$
y=\sqrt[n]{\frac{B^{n} \times x}{A-x}}
$$

Using Statistica 12.5 software (Tulsa, OK, USA), the variable parameters of equation (n, A, B) together with coefficients of correlation $(r)$ and coefficients of determination $\left(r^{2}\right)$ were calculated for each curve. The limits of detection (LOD) and quantification (LOQ) were evaluated by the signal-to-noise approach with the use of the lowest concentration. All results are given in Table 1. 
Table 1. Parameters of calibration Equation (1), for primulasaponins I (PSI), II (PSII) and sakurasosaponin (SSI), together with values of $r, r^{2}, L O D$ and LOQ.

\begin{tabular}{cccccccc}
\hline Standard & $\mathbf{n} \pm \mathbf{S D}$ & $\mathbf{A} \pm \mathbf{S D}$ & $\mathbf{B} \pm \mathbf{S D}$ & $\mathbf{r}$ & $\mathbf{r}^{\mathbf{2}}$ & $\mathbf{L O D}[\mathbf{n g} / \mathbf{m L}]$ & $\mathbf{L O Q}[\mathbf{n g} / \mathbf{m L}]$ \\
\hline PSI & $0.890 \pm 0.072$ & $4,574,451 \pm 83,044$ & $24.73 \pm 1.26$ & 0.9998 & 0.9996 & 6.7 & 20.3 \\
PSII & $0.776 \pm 0.110$ & $3,274,550 \pm 100,794$ & $23.41 \pm 2.24$ & 0.9994 & 0.9988 & 6.4 & 19.4 \\
SSI & $0.943 \pm 0.110$ & $3,951,182 \pm 86,066$ & $20.29 \pm 1.62$ & 0.9995 & 0.9990 & 7.4 & 22.5 \\
\hline
\end{tabular}

\subsubsection{Precision, Accuracy and Stability}

Precision, accuracy and stability were determined using standards at low, medium and high concentration levels $(1,10$ and $100 \mu \mathrm{g} / \mathrm{mL}$ for all saponins, corresponding to $0.2 \%, 2.0 \%$ and $20 \%$ of root dry mass). All concentration levels were measured in triplicate. The precision and accuracy were tested once a day and repeated for three consecutive days. Intra- and interday precision were defined as the relative standard deviation (RSD), while the accuracy was determined by the relative error (RE $\%$ ). The stability of analyzed saponins was assessed using standards stored at room temperature for 14 days in three repetitions. All results are gathered in Table 2.

Table 2. Validation parameters for UHPLC-MS assay for primulasaponins I (PSI), II (PSII) and sakurasosaponin (SSI).

\begin{tabular}{|c|c|c|c|c|c|c|}
\hline \multirow{2}{*}{$\begin{array}{c}\text { Standard } \\
\text { Level }\end{array}$} & \multicolumn{3}{|c|}{ Repeatability (RSD)/(Intra-Day Precision) } & \multicolumn{3}{|c|}{ Intermediate Precision (RSD)/(Inter-Day Precision) } \\
\hline & $1 \mu \mathrm{g} / \mathrm{mL}$ & $10 \mu \mathrm{g} / \mathrm{mL}$ & $100 \mu \mathrm{g} / \mathrm{mL}$ & $1 \mu \mathrm{g} / \mathrm{mL}$ & $10 \mu \mathrm{g} / \mathrm{mL}$ & $100 \mu \mathrm{g} / \mathrm{mL}$ \\
\hline PSI & 2.3 & 2.0 & 0.4 & 5.6 & 1.6 & 1.2 \\
\hline PSII & 4.0 & 1.7 & 0.7 & 6.1 & 1.5 & 1.1 \\
\hline SSI & 2.8 & 1.2 & 1.0 & 3.0 & 1.2 & 0.9 \\
\hline Standard & \multicolumn{3}{|c|}{ Accuracy (\%RE) } & \multicolumn{3}{|c|}{ Stability (RSD)/(14 days) } \\
\hline Level & $1 \mu \mathrm{g} / \mathrm{mL}$ & $10 \mu \mathrm{g} / \mathrm{mL}$ & $100 \mu \mathrm{g} / \mathrm{mL}$ & $1 \mu \mathrm{g} / \mathrm{mL}$ & $10 \mu \mathrm{g} / \mathrm{mL}$ & $100 \mu \mathrm{g} / \mathrm{mL}$ \\
\hline PSI & +21.2 & +3.5 & +0.1 & 3.2 & 3.3 & 2.6 \\
\hline PSII & +30.6 & +5.5 & -0.7 & 10.1 & 1.8 & 4.2 \\
\hline SSI & +15.4 & +4.8 & +0.4 & 6.8 & 2.2 & 1.4 \\
\hline
\end{tabular}

\subsection{Clustering of Saponin Concentrations}

Using Statistica 12.5 software (Tulsa, OK, USA), clustering analysis (CA) was performed to group the samples according to the content of each saponin. The results are presented at Figure 2 and Table 3.

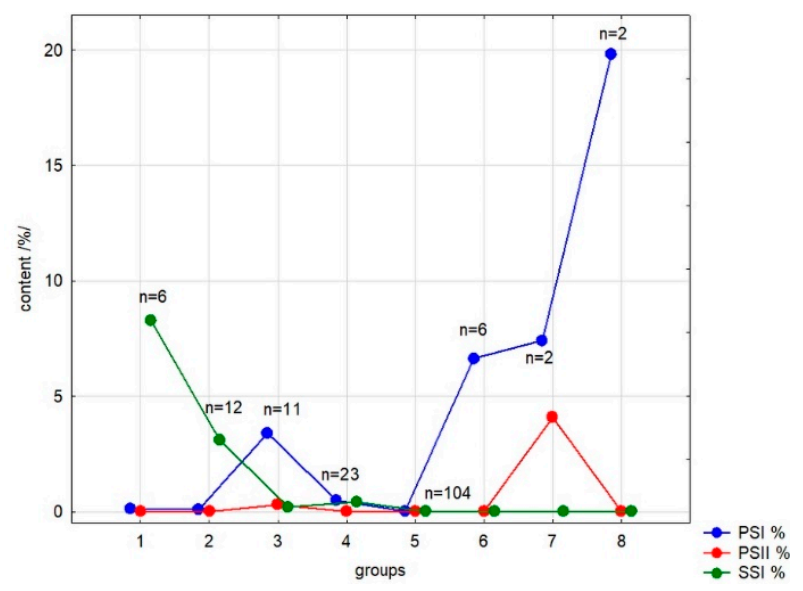

Figure 2. Visual representation of clustering analysis (CA) of analyzed Primulaceae taxa; based on the content of primulasaponins I, II and sakurasosaponin (PSI, PSII and SSI). 
Table 3. List of outstanding groups resulting from clustering analysis; corresponds with Figure 2.

\begin{tabular}{ccccccc}
\hline Sample Acronym & Group & Sample Acronym & Group & Sample Acronym & Group & Sample Acronym \\
\hline PFOR_K_2014 & 1 & HOIN_MO_2014 & 2 & PCHS_K_2015 & 3 & PCHI_K_2014 \\
POBC_K_2014 & 1 & PZAM_K_2014 & 2 & PAUA_K_2015 & 3 & PCHC_K_2015 \\
PTAK_E_2014 & 1 & PCOR_B_2013 & 2 & PROG_B_2013 & 3 & PLON_K_2014 \\
PCLE_K_2016 & 1 & PPOL_K_2015 & 2 & PCJG_K_2014 & 3 & PMAC_K_2015 \\
PTET_K_2014 & 1 & PSIE_K_2014 & 2 & PJEF_K_2015 & 3 & PWAR_K_2014 \\
PANG_K_2016 & 1 & PHEU_K_2015 & 2 & PELA_K_2014 & 3 & 6 \\
& & PPAL_K_2014 & 2 & PMEG_K_2015 & 3 & PR2 \\
& & PCUN_K_2016 & 2 & PVRS_K_2014 & 3 & PVUL_K_2014 \\
& & PCUH_K_2016 & 2 & PR3 & 3 & PR1 \\
& & PAUS_K_2014 & 2 & PR4 & 3 & 7 \\
& & PMEA_K_2014 & 2 & PMAG_B_2013 & 3 & PGRA_K_2014 \\
& & PPAU_K_2014 & 2 & & & PGRA_K_2016 \\
\hline
\end{tabular}

PR1-4-samples of commercial trade Primulae radix, declared to fulfill pharmacopoeial requirements. Background color corresponds with botanical classification: blue-sg. Auganthus, yellow—sg. Auriculastrum, sct. Dodecatheon, green-sg. Aleuritia, sct., Crystallophlomis, pink-sg. Aleuritia, sct. Oreophlomis, grey-sg. Primula, sct. Primula, brown—sg. Primula, sct. Sredinskya, transparent—others.

\section{Results}

\subsection{Method Development}

In our study, only species offered year by year in common trade in Europe were collected, trying to obtain at least 2-3 species from each available botanical section or subsection. Finally, 157 taxa were collected to perform the screening (collected in Table A1). The roots of the authenticated plants were sequentially dried, milled, extracted with $70 \% \mathrm{MeOH}$, filtered and diluted to obtain samples applicable for the assay. The universal extraction strategy was based on observations during the isolation process: SPE fractions eluted with $70 \% \mathrm{MeOH}$ from $\mathrm{C} 18$ bed were the richest in isolated saponins. Ultrasound-assisted extraction (UAE) is a common strategy for the rapid extraction of both fresh and dry plant material. It was first-choice when small amounts of plant material were available.

Because the reference substances of all mentioned saponins were not simply available, the standards were isolated from pharmacopoeial primrose roots (PSI and PSII) and the roots of Primula sieboldii (SSI). Their structures (Figure 1) were elucidated based on the following HRMS and NMR experiments. High-resolution mass spectrum measured for the investigated creamy amorphous solids in negative ion mode revealed the following main peaks: for PSI [M-H] $]^{-}$at $1103.5643 \mathrm{~m} / \mathrm{z}$ (calculated for $\mathrm{C}_{54} \mathrm{H}_{87} \mathrm{O}_{23} ; 1103.5644$ ), for PSII [M-H] ${ }^{-}$at $1235.6054 \mathrm{~m} / z$ (calculated for $\mathrm{C}_{59} \mathrm{H}_{95} \mathrm{O}_{27} ; 1235.6066$ ) and for SSI $[\mathrm{M}-\mathrm{H}]^{-}$at $1249.6241 \mathrm{~m} / z$ (calculated for $\mathrm{C}_{60} \mathrm{H}_{97} \mathrm{O}_{27}$ 1249.6223). The formulas generated for detected ions corresponded well to neutral molecules $\mathrm{C}_{54} \mathrm{H}_{88} \mathrm{O}_{23}$ (PSI), $\mathrm{C}_{59} \mathrm{H}_{96} \mathrm{O}_{27}$ (PSII) and $\mathrm{C}_{60} \mathrm{H}_{98} \mathrm{O}_{27}$ (SSI) and the MS/MS fragmentation of the glycone part was the additional proof. All HRMS and MS/MS spectra are attached to the Supplementary Figures S1 and S2. The detailed ${ }^{1} \mathrm{H}$ and ${ }^{13} \mathrm{C}$ NMR spectra, combined with COSY, HSQC and HMBC experiments, finally confirmed the identities of isolated compounds (Supplementary Figures S3-S5) with regard to the literature [12,13]. Table S1, summarizing NMR measurements, is attached to Supplementary Material. The purity level that is needed for the circumspect usage of isolated compounds in the quantitative analysis was calculated by qHNMR as $88.91 \%$ (PSI), 78.14\% (PSII) and 91.89\% (SSI).

Limited by the fact that the PSI, PSII and SSI saponins are not applicable for efficient and reliable HPLC-UV analysis due to the lack of conjugated double bonds except carbonyl groups, we used a previously developed simple UHPLC-ESI-MS analytical method for their precise quantitative evaluation [32]. On its basis, a qualitative method was proposed to rapidly estimate the concentrations. A non-standard curve (1) (Table 1) was fit to cover the response of the detector in a broad range of concentrations $(0.050-250 \mu \mathrm{g} / \mathrm{mL}$, relative to $0.01-50 \%$ of root dry mass). The correlation coefficients were all of 0.999 . The LOQ values were between 19 and $23 \mathrm{ng} / \mathrm{mL}$.

The full validation of the quantitative method was intentionally not performed at this level of research; however, some data are collected in Table 2 to supply the assay. Values of inter-day and 
intra-day precision are acceptable, while low accuracy at the lowest level suggested the measurement uncertainty and need to use higher concentrations. The standards seemed to be stable in two weeks at room temperature.

The MS detector was calibrated before each UHPLC analysis to guarantee accuracy. Samples were separated by blank analyses to exclude the possibility of overlapping. The low flow of chromatographic solvents together with the relatively fast gradient program resulted in eco-friendliness. The primarily considered faster way of HRMS quantitative analysis in the "direct injection mode" (without LC) was rejected because of the detection of ions isobaric to PSI and SSI in some of the first chromatograms. These ions were sufficiently separated from analytes and did not affect the area readings.

\subsection{Distribution of Saponins}

Figure 2 and Table 3 show the result of K-means clustering (CA). Table 4 shows in the form of a heatmap the average concentrations of analyzed saponins in roots of 157 Primulaceae members (> 165 samples). Only the exemplars with the saponin level exceeding $0.20 \%$ were presented with percentages (calculated from root dry mass) in the Appendix A, Table A2. The concentrations of PSI, PSII and SSI were under the LOD or the compounds were present in trace amounts in representatives of genera Cortusa L. (also considered as a part of the Primula L. [35]), Dionysia Fenzl., Lysimachia L., Omphalogramma Franch., Soldanella L., Vitaliana Sesl. and in a part of Androsace L.

\subsubsection{Distribution of Primulasaponins}

The presence of both PSI and PSII was established to be typical only for the genus Primula L. and subgenus Primula (0.1-6.2\% and 0-3.3\% respectively). PSII was not found in considerable amounts elsewhere. Moreover, the second compound was found in significant amounts, exceeding $2 \%$ in roots of only two species, P. vulgaris Huds. and P. megaseifolia Boiss. \& Bal. Contrary to PSII, the saponin PSI was also present in Primula L., subgenus Aleuritia (Duby) Wendelbo, in sections Crystallophlomis (Rupr.) Federov (0.1-9.5\%), Davidii Balf. f. (<1\%), Oreophlomis (Rupr.) Federov (1.7-5.2\%) and Petiolares Pax (about 1\%). Among Proliferae-belonging taxa, only P. japonica reached the level of $1 \%$ of PSI. In members of subgenera Auganthus (Link) Wendelbo and Auriculastrum Schott only trace amounts of PSI were found except for Primula parryi A. Grey roots ( 1\%). Primula grandis L., a single representative of Primula L., section Sredinskya Stein was newly found to concentrate the highest amounts of PSI among all samples (15-20\%). After this observation, a similar level of concentration was also found in its remarkably fleshy rhizomes.

Some years ago, the genus Dodecatheon L. was proposed to be included in Primula L. based on genetic analyses [36]. Our findings on PSI concentrations in 7 species from the Dodecatheon L. were generally similar to its relative subgenus Auriculastrum. However, two former Dodecatheon members-P. conjugens (Greene) Mast \& Reveal and P. jeffreyi (van Houtte) Mast \& Reveal—were quite abundant in PSI saponin (3.9\% and $2.9 \%$ respectively).

\subsubsection{Distribution of Sakurasosaponin}

Sakurasosaponin, primarily detected and described only in P. sieboldii E. Morren, was found to be typical for almost all of its analyzed relatives from the subgenus Auganthus (Link) Wendelbo (range of $1.1-9.1 \%)$. Its presence in the subgenus Auriculastrum Schott, section Cuneifolia Balf. f. (2.3-3.3\%) and former genus Dodecatheon L. (0.7-8.6\%) is noteworthy. Particularly high amounts of SSI were newly discovered in P. forrestii Balf. f. $(\sim 8 \%)$, P. obconica Hance and P. takedana Tatew. (both $>8 \%)$. P. jesoana Miq was found to be the only species from the subgenus Auganthus in which sakurasosaponin was absent. Relatively small amounts of SSI were detected in both Hottonia specimens (0.6-2.3\%) and several representatives of Androsace (0.1-1.3\%). 
Table 4. A heatmap of average primulasaponins I and II and sakurasosaponin distribution in Primulaceae family. Highest concentration-red, lowest concentration-green.

\begin{tabular}{|c|c|c|c|c|c|c|c|c|c|c|c|c|c|c|}
\hline Taxon & $\mathbf{n}$ & $\tilde{\omega}$ & $\vec{w}$ & $\vec{w}$ & Taxon (Continuation) & $\mathbf{n}$ & $\tilde{\infty}$ & 苞 & $\vec{w}$ & Taxon (Continuation) & $\mathbf{n}$ & $\bar{n}$ & $\overrightarrow{\tilde{\omega}}$ & w \\
\hline genus Primula L., sg. Aleuritia & & & & & genus Primula L., sg. Auganthus & & & & & genus Androsace $\mathrm{L}$. & & & & \\
\hline sct. Aleuritia, ssct. Aleuritia & 3 & & & & sct. Bullatae & 2 & & & & sct. Aizodium & 1 & & & \\
\hline sct. Aleuritia, ssct. Algida & 2 & & & & sct. Cortusoides, ssct. Cortusoides & 3 & & & & sct. Andraspis & 1 & & & \\
\hline sct. Armerina & 5 & & & & sct. Cortusoides, ssct. Geraniifolia & 4 & & & & sct. Aretia, ssct. Aretia & 3 & & & \\
\hline sct. Capitatae & 2 & & & & sct. Obconicolisteri & 1 & & & & sct. Aretia, ssct. Dicranothrix & 3 & & & \\
\hline sct. Crystalophlomis & 1 & & & & sct. Reinii & 1 & & & & sct. Chamaejasme, ssct. Hookerianae & 1 & & & \\
\hline sct. Crystalophlomis, ssct. Crystalophlomis & 7 & & & & genus Primula L., sg. Auriculastrum & & & & & sct. Chamaejasme, ssct. Mucronifoliae & 3 & & & \\
\hline sct. Crystalophlomis, ssct. Maximowiczii & 3 & & & & sct. Amethystina & 1 & & & & sct. Chamaejasme, ssct. Strigillosae & 2 & & & \\
\hline sct. Davidii & 2 & & & & sct. Auricula, ssct. Arthritica & 2 & & & & sct. Chamaejasme, ssct. Sublanatae & 2 & & & \\
\hline sct. Denticulata & 3 & & & & sct. Auricula, ssct. Auricula & 1 & & & & sct. Chamaejasme, ssct. Villosae & & & & \\
\hline sct. Minutissimae & 1 & & & & sct. Auricula, ssct. Brevibracteatum & 3 & & & & series Chamaejasmoidae & 3 & & & \\
\hline sct. Muscarioides & 3 & & & & sct. Auricula, ssct. Chamaecallis & 2 & & & & series Euvillosae & 3 & & & \\
\hline sct. Oreophlomis & 4 & & & & sct. Auricula, ssct. Cyanaster & 1 & & & & sct. Douglasia & 1 & & & \\
\hline sct. Petiolares, ssct. Edgeworthii & 2 & & & & sct. Auricula, ssct. Erythrodosum & 2 & & & & sct. Pseudoprimula & 1 & & & \\
\hline sct. Petiolares, ssct. Griffithii & 2 & & & & sct. Auricula, ssct. Rhopsidium & 3 & & & & & & & & \\
\hline sct. Petiolares, ssct. Petiolares & 1 & & & & sct. Auricula, hybrids & 2 & & & & genus Cortusa $\mathrm{L}$. & 6 & & & \\
\hline sct. Petiolares, ssct. Sonchifolia & 1 & & & & sct. Cuneifolia & 2 & & & & genus Dionysia Fenzl. & 2 & & & \\
\hline sct. Proliferae & 5 & & & & sct. Dodecatheon & 8 & & & & genus Hottonia $\mathrm{L}$. & 2 & & & \\
\hline sct. Pulchella & 3 & & & & sct. Parryi & 3 & & & & genus Lysimachia $\mathrm{L}$. & 2 & & & \\
\hline sct. Sikkimensis & 6 & & & & genus Primula L., sg. Primula & & & & & genus Omphalogramma (Franch.) Franch. & 2 & & & \\
\hline sct. Soldanelloides & 2 & & & & sct. Primula & 6 & & & & genus Soldanella $\mathrm{L}$. & 6 & & & \\
\hline sct. Yunnanensis & 2 & & & & sct. Sredinskya & 1 & & & & genus Vitaliana Sesl. & 3 & & & \\
\hline genus Primula, sg. Sphondyllia & 2 & & & & sct. Primula, hybrids & 1 & & & & & & & & \\
\hline
\end{tabular}

hb_-herb was used instead of roots; sg.—subgenus, sct.—section, ssct.—subsection, ssp.—subspecies, var.—variety, n—number of analyzed taxa in genus, section or subsection. 


\subsubsection{Results of Clustering Analysis}

K-means clustering led to the separation of a dataset into eight groups of different numbers (Figure 2). The most numerous group 5 consists of samples containing no one of analyzed compounds at a concentration higher than $0.2 \%$; the second numerous group 4 contains samples with poor concentrations of all three saponins. Group 2 collects the samples with medium amounts of the sakurasosaponin (mainly from subgenus Auganthus-section Cortusoides and subgenus Auriculastrum - sections Cuneifolia and Dodecatheon) while samples containing large amounts of this compound are gathered in group 1 (exemplars from subgenera Auganthus-P. forrestii, P. obconica, P. takedana-and Auriculastrum-P. angustifolia, P. clevelandii and P. tetrandra). Group 3 consists of samples with an medium content of primulasaponin I, groups 6 and 7-high content of this compound (in case of group 7, accompanied by significant amounts of primulasaponin II). Samples very rich in single primulasaponin I from subgenus Primula, section Sredinskya are in group 8. Ascriptions of samples to groups $1-3$ and 6-8 are presented in Table 3.

\section{Discussion}

The lack of high-yielding or single-compound-yielding plant sources of active constituents is a common problem for institutions that develop standardization procedures of herbal drugs and those involved in deep research or clinical studies. In order to improve the quality and the value of medicinally important crops, several attempts are made in different fields. Some try to modify environmental conditions. Others try modern genetic manipulations. The recent trends in this area are also focused on the importance of soil microorganisms and mycorrhizal fungi [37,38]. The old strategy to increase the production of crucial secondary metabolites is to conduct organized selection of better-yielding cultivars, varieties or hybrids. The latter approach may still work successfully since 21st-century knowledge on medicinal plants is still rudimentary.

To find new and abundant sources of primulasaponins I and II and closely related sakurasosaponin, over 155 taxa of Primulaceae members were analyzed by the newly designed universal method. Most of them were not previously mentioned in the literature in the phytochemical context. Limited by the fact that the PSI, PSII and SSI saponins are not applicable for efficient HPLC-UV analysis, a simple UHPLC-ESI-MS analytical method was developed for this purpose. Previously UHPLC-APCI-MS, in comparison with UHPLC-ELSD, was used for PSI and PSII quantification in pharmacopoeial herbal drugs [7]. For assay purposes, the standards of both primulasaponins (PSI and PSII) were isolated from the pharmacopoeial primula root while sakurasosaponin (SSI) was isolated from the roots of $P$. sieboldii by LC and FC. The identity of compounds was confirmed by comparison of spectrometric and spectroscopic data (HRMS, MS/MS and NMR) with the literature [12,13], while their purity was determined by qHNMR.

According to the literature, the saponin content in Primula species may vary from $2 \%$ to $12 \%$ but the exact range of expectation is not defined in the monographs [9-11]. Our study shows that the roots of non-pharmacopoeial primroses may be an alternative source for PSI isolation, sometimes exceeding the level of $10 \%$. Some of the selected species exhibit vigorous growth and are not very difficult to propagate (P. conjugens, P. chionantha, P. macrophylla, P. vulgaris). The other primarily promiscuous well-growing ones (e.g., from the section Proliferae) do not serve this purpose due to the lack of saponins mentioned above. Primula grandis L., a single representative of the section Sredinskya, should be considered as a particularly valuable source of this saponin. The reasons are as follows: almost complete exclusiveness of PSI in the saponin profile of this source (Figure S1), its unusual concentration exceeding $15-20 \%$ of both root and rhizome dry mass, together with significant growth and hardiness of this species.

Sakurasosaponin, which was previously reported only from $P$. sieboldii, appears to be typical for many Auganthus and Dodecatheon members. For example, P. takedana and P. obconica may yield reasonable amounts of this compound with almost no coexisting saponins. The structure of this compound (SSI) is quite similar to those of PSI and PSII. The above, together with the ethnomedicinal 
applications of $P$. sieboldii, should lead soon to the consideration of SSI as a substitute for PSI and PSII or their mixtures (in the form of extracts).

The information presented in the Figure 2 and Tables 3 and 4 could be valuable as supplementary data for taxonomists analyzing phylogenetic relationships in this family $[39,40]$. Some previously underestimated species should be recognized as remarkably useful for the pharmaceutical industry.

Frequently, phytochemical studies are limited to a few species and use different methods. Here, by using a unified approach, a reasonable number of plant species was tested. The samples were supplied for seven consecutive years (2013-2019) to cover the maximal number of Primulaceae species available in commercial trade. Attempts were made to sufficiently cover the number of representatives in each section. It allowed us to select some notable cases. In the light of the presented results, ornamental hybrids and varieties of Primula species belonging to the subgenera Primula and Auganthus were selected to continue the systematic exploration. This sizeable comparative study is a good starting point for further research covering seasonal and environmental saponin variation as well as for establishing metabolomic relationships among primroses.

This work presents the first systematic study of three 13,28-epoxy-oleanane-type saponins (PSI, PSII, SSI) in the genus Primula by UHPLC-ESI-MS. Although the mentioned saponins were previously not a subject of any clinical study, the discovery of abundant and single-compound sources of primulasaponins and sakurasosaponin should be a milestone in studies on their activities. As pure substances, they can be used directly or for structural modifications. The area of semisynthesis of new enzyme inhibitors and antibacterial or anti-protozoan agents is fertile. One direction for the application of their derivatives is a study on their cytotoxicity or modulation of action of well-known cytotoxic or antimicrobial agents.

Supplementary Materials: The following are available online at http://www.mdpi.com/2218-273X/10/3/376/s1, Figure S1: UHPLC-HRMS chromatograms of compounds PSI, PSII and SSI (EIC, negative mode) together with chromatograms of selected high-yielding primroses (TIC, negative mode). Figure S2: HRMS spectra and MS/MS fragmentation of compounds PSI, PSII and SSI. Figure S3: 1D and 2D NMR spectra of PSI. Figure S4: 1D and 2D NMR spectra of PSII. Figure S5: 1D and 2D NMR spectra of SSI. Figure S6: Purity determination protocol of compounds PSI, PSII and SSI. Table S1: ${ }^{1} \mathrm{H}$ and ${ }^{13} \mathrm{C}$ NMR data of PSI, PSII and SSI.

Author Contributions: Conceptualization, M.W.; methodology, M.W., M.G. and P.P.; software, A.D.; validation, M.W.; formal analysis, A.D., M.W.; investigation, K.O. (PSI, PSII), A.F. (SSI), M.W., P.P. and M.G.; resources, M.W., P.P. and M.G.; writing—original draft preparation, M.W.; writing-review and editing, M.W., M.G. and P.P.; visualization, M.W.; supervision, M.W. and M.G.; project administration, M.W.; funding acquisition, M.W. All authors have read and agreed to the published version of the manuscript.

Funding: This research was funded by Wroclaw Medical University, grant number ST-858. This publication was co-funded by Council of Pharmaceutical Sciences at the Wroclaw Medical University.

Acknowledgments: UHPLC-MS and NMR analyses were carried out in the Laboratory of Elemental Analysis and Structural Research, Faculty of Pharmacy, Wroclaw Medical University. The technical assistance of Czapor-Irzabek, H. and Szczepaniak Z. (Wroclaw Medical University) is acknowledged. The authors would like to thank the students Łagowska, A. and Niedzwiecka, M. for their laboratory help. The authors are grateful to all plant donators (mentioned in Table A1) who helped in conducting this screening.

Conflicts of Interest: The authors declare no conflict of interest. The funders had no role in the design of the study; in the collection, analyses or interpretation of data; in the writing of the manuscript; or in the decision to publish the results. 


\section{List of Abbreviations}

$[\mathrm{M}-\mathrm{H}]^{-} \quad$ Pseudomolecular Ion (deprotonated molecule)

2D Two Dimensional (experiment in NMR)

A. Androsace

APCI Atmospheric-Pressure Chemical Ionization

COSY $\quad{ }^{1} \mathrm{H}_{-}{ }^{1} \mathrm{H}$ Correlated Spectroscopy (experiment in NMR)

ELSD Evaporative Light Scattering Detector

ESI Electrospray Ionization

EU European Union

H. Hottonia

$\mathrm{HCOOH} \quad$ Formic Acid

HMBC Heteronuclear Multiple Bond Correlation (experiment in NMR)

HRMS High-Resolution Mass Spectrometry

HSQC Heteronuclear Single Quantum Correlation (experiment in NMR)

LOD Limit of Detection

LOQ Limit of Quantification

LC Liquid Chromatography

LC-MS Liquid Chromatography coupled with Mass Spectrometry Detector

LC-UV Liquid Chromatography coupled with Ultraviolet Absorbance Detector

$\mathrm{MeOH} \quad$ Methanol

MS/MS Tandem Mass Spectrometry

NMR Nuclear Magnetic Resonance (Spectroscopy)

P. Primula

PSI Primulasaponin I

PSII Primulasaponin II

qHNMR Quantitative Proton Nuclear Magnetic Resonance (Spectroscopy)

$r \quad$ Coefficient of Correlation

$\mathrm{r}^{2} \quad$ Coefficient of Determination

RE Relative Error

RSD Relative Standard Deviation

sct. Section

SD Standard Deviation

sg. Subgenus

SPE Solid-Phase Extraction

ssct. Subsection

ssp. Subspecies

SSI Sakurasosaponin

TLC Thin-Layer Chromatography

UAE Ultrasound-Assisted Extraction

UHPLC Ultra-High-Performance Liquid Chromatography

var. variety 


\section{Appendix A}

Table A1. List of Primulaceae species used for screening in this study.

\begin{tabular}{|c|c|c|c|}
\hline Taxon (a) & Acronym & Taxon (b) & Acronym \\
\hline $\begin{array}{l}\text { genus Primula } \mathbf{L} \text {. } \\
\text { sg. Aleuritia, sct. Aleuritia, ssct. Aleuritia }\end{array}$ & & sg. Aleuritia, sct. Minutissimae & \\
\hline $\begin{array}{l}\text { sg. Aleuritia, sct. Aleuritia, ssct. Aleuritia } \\
\text { Primula halleri }\end{array}$ & PHAL_P 2013, PHAL_K_ 2016 & $\begin{array}{l}\text { Primula primulina } \\
\text { sg. Aleuritia, sct. Muscarioides }\end{array}$ & PPRI_P_2014 \\
\hline Primula scandinavica & PSCA_B_2013 & Primula concholoba & PCON_K_2014 \\
\hline Primula scotica & PSCO_K_2016 & Primula muscarioides & PMUS_P_2013 \\
\hline sg. Aleuritia, sct. Aleuritia, ssct. Algida & & Primula vialii & PVIA_B_2013 \\
\hline Primula algida & PALG_K_2014 & sg. Aleuritia, sct. Oreophlomis & \\
\hline Primula darialica & PDAR_K_2014 & Primula auriculata & PAUA_K_2015 \\
\hline sg. Aleuritia, sct. Armerina & & Primula luteola & PLUT_K_2015 \\
\hline Primula fasciculata & PFAS_K_2014 & Primula rosea 'Gigas' & PROG_B_2013 \\
\hline Primula involucrata & PINV_P_2015 & Primula warschenewskiana & PWAR_K_2014 \\
\hline Primula munroi ssp. yargongensis (->P. involucrata in [1]) & PMUY_P_P2015 & sg. Aleuritia, sct. Petiolares, ssct. Edgeworthii & \\
\hline Primula yargongensis ( $(>P$. involucrata in [1]) & PYAR_P_2015 & Primula moupinensis & PMOU_GP_2014 \\
\hline Primula zambalensis & PZAM_K_2014 & Primula moupinensis ssp. barkamensis & PMOB_K_2015 \\
\hline sg. Aleuritia, sct. Capitatae & & sg. Aleuritia, sct. Petiolares, ssct. Griffithii & \\
\hline Primula capitata ssp. mooreana & PCAM_B_2013 & Primula calderiana ssp. calderiana & PCAL_K_2014 \\
\hline Primula glomerata & PGLO_K_2014 & Primula tanneri ssp. nepalensis & PTNN_K_2014 \\
\hline sg. Aleuritia, sct. Crystalophlomis & & sg. Aleuritia, sct. Petiolares, ssct. Petiolares & \\
\hline Primula purdomii & PPUR_P_2014 & Primula boothi var. repens & PBOR_K_2014 \\
\hline sg. Aleuritia, sct. Crystalophlomis, ssct. Crystalophlomis & & sg. Aleuritia, sct. Petiolares, ssct. Sonchifolia & \\
\hline Primula chionantha & PCHI_K_2014 & Primula sonchifolia ssp. sonchifolia & PSON_K_2014 \\
\hline Primula chionantha ssp. chionantha & PCHC_K_2015 & sg. Aleuritia, sct. Proliferae & \\
\hline Primula chionantha ssp. sinopurpurea & PCHS_K_2015 & Primula beesiana & PBES_B_2013 \\
\hline Primula graminifolia $(->P$. chionantha in [1]) & PGRM_P_2015 & Primula bulleyana & PBUL_B_2013 \\
\hline $\begin{array}{l}\text { Primula longipetiolata } \\
\text { Pal }\end{array}$ & PLON_K_2014 & $\begin{array}{l}\text { Primula japonica } \\
\text { Pan }\end{array}$ & PJAP_B_2013 \\
\hline Primula macrophylla & PMAC_K_2015 & Primula prolifera & PPRO_K_2015 \\
\hline Primula orbicularis & PORB_K_2015, PORB_P_2015 & Primula wilsonii var. anisodora & PWIA_K_2015 \\
\hline sg. Aleuritia, sct. Crystalophlomis, ssct. Maximowiczii & & sg. Aleuritia, sct. Pulchella & \\
\hline Primula maximowiczii var. maximowiczzii & PMAX_K_2014 & Primula pulchella & PPUL_K_2015, PPUL_P_2015 \\
\hline Primula tangutica & PTAN_P_2013 & Primula sharmae & PSHA_K_2016 \\
\hline Primula woodwardii & PWOD_P_2013, PWOD_P_2014 & Primula stenocalyx & PSTE_P_2013, PSTE_P_2014 \\
\hline sg. Aleuritia, sct. Davidii & & sg. Aleuritia, sct. Sikkimensis & \\
\hline Primula bergenioides & PBER_K_2015 & Primula firmipes & PFIR_K_2014 \\
\hline Primula ovaliifolia & POVA_K_2015 & Primula florindae & PFLO_B_2013 \\
\hline sg. Aleuritia, sct. Denticulata & & Primula florindae, red flowered & PFLR_K_2015 \\
\hline Primula denticulata 'Alba' & PDEA_B_2013 & Primula ioessa & PIOE_P_2013 \\
\hline Primula denticulata & PDEN_K_2016 & Primula sikkimensis & PSIK_K_2014 \\
\hline Primula monticola & PMON_K_2014, PMON_K_2015 & Primula waltonii & PWAL_K_2014 \\
\hline
\end{tabular}


Table A1. Cont.

\begin{tabular}{|c|c|c|c|}
\hline Taxon (c) & Acronym & Taxon (d) & Acronym \\
\hline sg. Aleuritia, sct. Soldanelloides & & sg. Auriculastrum, sct. Auricula, ssct. Erythrodosum & \\
\hline Primula reidii & PREI_K_2016 & Primula daoensis & PDAO_K_2014 \\
\hline Primula reidii var. williamsii 'Alba' & PREW_F_2015 & Primula hirsuta & PHIR_P_2013 \\
\hline sg. Aleuritia, sct. Yunnanensis & & sg. Auriculastrum, sct. Auricula, ssct. Rhopsidium & \\
\hline Primula florida (P. blinii) & PBLI_P_2013, PBLI_P_2014 & Primula allionii & PALL_F_2015 \\
\hline Primula rupicola & PRUP_K_2016 & Primula integrifolia & PINT_P_2013 \\
\hline sg. Auganthus, sct. Bullatae & & Primula tyrolensis & PTYR_TK_2015 \\
\hline Primula bullata var. rufa & PBUR_K_2014 & sg. Auriculastrum, sct. Auricula, hybrids & \\
\hline Primula forrestii & PFOR_K_2014 & Primula venusta & PVEN_B_2013 \\
\hline sg. Auganthus, sct. Cortusoides, ssct. Cortusoides & & Primula allioni $\times$ Primula villosa & PXAV_P_2013 \\
\hline Primula cortusoides & PCOR_B_2013 & sg. Auriculastrum, sct. Cuneifolia & \\
\hline Primula polyneura & PPOL_K_2015 & Primula cuneifolia & PCUN_K_2016 \\
\hline Primula sieboldii & PSIE_K_2014 & Primula cuneifolia ssp. heterodonta & PCUH_K_2016 \\
\hline sg. Auganthus, sct. Cortusoides, ssct. Geraniifolia & & sg. Auriculastrum, sct. Dodecatheon & \\
\hline Primula heucheriifolia & PHEU_K_2015 & Primula austrofrigida & PAUS_K_2014 \\
\hline Primula jesoana & PJES_K_2014 & Primula clevelandii & PCLE_K_2016 \\
\hline Primula kisoana & PKIS_K_2015 & Primula conjugens & PCJG_K_2014 \\
\hline Primula palmata & PPAL_K_2014 & Primula jeffreyi & PJEF_K_2015, PJEF_K_2016 \\
\hline sg. Auganthus, sct. Obconicolisteri & & Primula latiloba & PLLB_K___2014 \\
\hline Primula obconica & POBC_K_2014 & Primula meadia & PMEA_K_2014 \\
\hline sg. Auganthus, sct. Reinii & & Primula pauciflora & PPAU_K_2014 \\
\hline Primula takedana & PTAK_E_2014 & Primula tetrandra & PTET_K_2014 \\
\hline sg. Auriculastrum, sct. Amethystina & & sg. Auriculastrum, sct. Parryi & \\
\hline Primula amethystina var. brevifolia & PAMB_K_2015 & Primula angustifolia & PANG_K_2016 \\
\hline sg. Auriculastrum, sct. Auricula, ssct. Arthritica & & Primula parryi & PPAR_K_2014 \\
\hline Primula glaucescens ssp. longobarda & PGLL_P_2013, PGLL_P_2014 & Primula rusbyi & PRUS_K_2014 \\
\hline Primula spectabilis & PSPE_P_2013 & sg. Primula, sct. Primula & \\
\hline sg. Auriculastrum, sct. Auricula, ssct. Auricula & & Primula elatior & PELA_K_2014 \\
\hline Primula auricula & PAUR_B_2013 & Primula elatior var. amoena & PAMO_P_2014 \\
\hline sg. Auriculastrum, sct. Auricula, ssct. Brevibracteatum & & Primula juliae & PJUL_B_2013 \\
\hline Primula carniolica & PCAR_K_2014, PCAR_K_2015 & Primula megaseifolia & PMEG_K_2015 \\
\hline Primula latifolia 'Alba' & PLAA_P_2013 & Primula veris (syn. P. officinalis) & PVRS_K_2014 \\
\hline Primula marginata & PMGN_P_2013 & Primula vulgaris & PVUL_K_2014 \\
\hline sg. Auriculastrum, sct. Auricula, ssct. Chamaecallis & & sg. Primula, sct. Sredinskya & \\
\hline Primula minima & PMIN_I_2014 & Primula grandis & PGRA_K_2014, PGRA_K_2016 \\
\hline Primula minima f. niveum & PNIV_P_2014 & sg. Primula, hybrids & \\
\hline sg. Auriculastrum, sct. Auricula, ssct. Cyanaster & & Primula margotae 'Garryarde Guinevere' & PMAG_B_2013 \\
\hline Primula glutinosa & PGLU_P_2013 & $\begin{array}{l}\text { sg. Sphondyllia } \\
\text { Primula } \times \text { kerwensis } \\
\text { Primula verticillata }\end{array}$ & $\begin{array}{l}\text { PXKE_K_2016 } \\
\text { PVRT K } 2014\end{array}$ \\
\hline
\end{tabular}


Table A1. Cont.

\begin{tabular}{|c|c|c|c|}
\hline Taxon (e) & Acronym & Taxon (f) & Acronym \\
\hline $\begin{array}{l}\text { genus Androsace } \mathbf{L} \text {. } \\
\text { sct. Andraspis }\end{array}$ & & $\begin{array}{l}\text { sct. Aizodium } \\
\text { Androsace bulleyana }\end{array}$ & ABUL_F_2015 \\
\hline $\begin{array}{l}\text { Androsace albana } \\
\text { sct. Aretia, ssct. Aretia }\end{array}$ & AALB_K_2019 & $\begin{array}{l}\text { genus Cortusa } \mathbf{L} . \\
\text { Cortusa matthioli }\end{array}$ & CMAT_P_2013 \\
\hline Androsace cylindrica & ACYL_K_2015 & Cortusa matthioli ssp. matthioli & CMAT_K_2015 \\
\hline Androsace lehmannii & ALEH_P_2014 & Cortusa matthioli ssp. caucasica & CCAU_K_2015, CCAU_K_2016 \\
\hline Androsace mathildae & AMTH_TK_2015 & Cortusa matthioli ssp. sachalinensis & CSAC_P_2013, CSAC_K_2015 \\
\hline sct. Aretia, ssct. Dicranothrix & & Cortusa matthioli ssp. turkestanica & CTUR_P_2013 \\
\hline Androsace lacteal & ALAC_TK_2015 & genus Dionysia Fenzl. & \\
\hline Androsace laggeri ( $=$ A. carnea var. laggeri) & ACAL_P_2014 & Dionysia khatamii & DKHA_F_2015 \\
\hline Androsace obtusifolia & AOBT_P_2014 & Dionysia zschummelii & DZSH_F_2015 \\
\hline $\begin{array}{l}\text { sct. Chamaejasme, ssct. Hookerianae } \\
\text { Androsace limprichtii } \\
\text { sct. Chamaejasme, ssct. Mucronifoliae }\end{array}$ & ALIM_P_2014 & $\begin{array}{l}\text { genus Hottonia } \mathrm{L} \text {. } \\
\text { Hottonia inflata } \mathrm{hb} \\
\text { Hottonia palustris } \mathrm{hb}\end{array}$ & $\begin{array}{l}\text { HOIN_MO_2014 } \\
\text { HOPA_PG_2014 }\end{array}$ \\
\hline Androsace mariae var. tibetica & AMAT_P_2014 & genus Lysimachia $\mathrm{L}$. & \\
\hline Androsace mucronifolia & AMUC_TK_2015 & Lysimachia nummularia 'Gold' & LYNG_PG_2014 \\
\hline Androsace sempervivoides & ASPV_B_2015 & Lysimachia thyrsiffora & LYTH_MO_2014 \\
\hline sct. Chamaejasme, ssct. Strigillosae & & genus Omphalogramma (Franch.) Franch. & \\
\hline Androsace spinulifera & ASPI_P_2015 & Omphalogramma delavayi & ODEL_PO_2019 \\
\hline Androsace strigillosa & ASTR_P_2014 & Omphalogramma tibeticum & OTIB_K_2019 \\
\hline sct. Chamaejasme, ssct. Sublanatae & & genus Soldanella $\mathrm{L}$. & \\
\hline Androsace adenocephala & AADE_F_2015 & sct. Crateriflorae & \\
\hline Androsace nortonii & ANOR_P_2014 & Soldanella alpina & SALP_K_2016 \\
\hline sct. Chamaejasme, ssct. Villosae, series Chamaejasmoidae & & Soldanella carpatica & SCAR_K_2014 \\
\hline Androsace brachystegia & ABRA_P_2014 & Soldanella cyanaster & SCYA_K_2014 \\
\hline Androsace chamaejasme ssp. carinata & ACHC_P_2014 & Soldanella dimoniei & SDIM_K_2014 \\
\hline Androsace zambalensis & AZAM_P_2014 & Soldanella villosa & SVIL_K_2014 \\
\hline sct. Chamaejasme, ssct. Villosae, series Euvillosae & & sct. Tubiflorae & \\
\hline Androsace dasyphylla & ADAS_P_2014 & Soldanella minima & SMIN_F_2015, SMIN_TK_2015 \\
\hline Androsace robusta ssp. purpurea & AROP_P_2014 & genus Vitaliana Sesl. & \\
\hline Androsace sarmentosa & ASAR_K_2015 & Vitaliana primuliflora & VPRI_B_2015 \\
\hline sct. Pseudoprimula & & Vitaliana primuliflora ssp. assoana & VPAS_TK_2015 \\
\hline Androsace elatior & AELA_F_2015 & Vitaliana primuliflora ssp. praetutiana & VPPR_B_2015, VPPR_B_2017 \\
\hline sct. Douglasia & & & \\
\hline Androsace montana (= Douglasia montana) & AMON_F_2015 & & \\
\hline
\end{tabular}

hb_herb was used instead of roots; sg.—subgenus, sct.-section, ssct.—subsection, ssp.—subspecies, var.—variety. The meaning of acronyms used to avoid long plant names in storage and during research is as follows: First letter-genus, three following letters-taxon (species; optionally together with variety), next separated letter or two-donator abbreviation and year of collection in the end. Donators abbreviations: B-Bergenia, Nursery, Paweł Weinar, Kokotów, Poland; E-Edrom, Nursery, Terry and Cath Hunt, Coldingham, UK; F-Floralpin, Nursery, Frank Schmidt, Waldenbuch, Germany; G-Private Collection, Gunhild and Thorkild Poulsen, Aldershvile, Denmark; I-Alpine Garden Mt. Patscherkofel, Institute of Botany, Innsbruck University, Peter Daniel Schlorhaufer, Innsbruck, Austria; K-Kevock Garden, Nursery, Stella and David Rankin, Lasswade, UK; MO-Mayla Ogrody, Nursery, Dawid Stefaniuk, Siedlakowice, Poland; P-Josef and Bohumila Plocar, Nursery, Švihov, Czech Republic; PG—Planta Garden, Krzysztof Sternal, Dobra, Poland; PO—Pottertons, Nursery, Jackie and Robert Potterton, Nettleton, UK; TK—Private Collection, Tomasz Kubala, Poland. 
Table A2. Content of primulasaponin I, II and sakurasosaponin (PSI, PSII and SSI, relatively) in roots of selected Primulaceae species.

\begin{tabular}{|c|c|c|c|c|c|c|c|c|c|c|c|}
\hline \multirow{2}{*}{ Taxon (a) } & \multicolumn{3}{|c|}{ Average $\%$ of Dry Mass } & \multirow{2}{*}{ Taxon (b) } & \multicolumn{3}{|c|}{ Average $\%$ of Dry Mass } & \multirow{2}{*}{ Taxon (c) } & \multicolumn{3}{|c|}{ Average $\%$ of Dry Mass } \\
\hline & PSI & PSII & SSI & & PSI & PSII & SSI & & PSI & PSII & SSI \\
\hline genus Primula & & & & sg. Auganthus, sct. Bullatae & & & & sg. Auriculastrum, sct. Cuneifolia & & & \\
\hline sg. Aleuritia, sct. Armerina & & & & P. bullata var. rufa & nd & nd & 1.07 & P. cuneifolia & $\mathrm{Nd}$ & nd & 2.31 \\
\hline P. zambalensis & $\mathrm{t}$ & nd & 2.97 & P. forrestii & $t$ & nd & 8.00 & P. cuneifolia ssp. heterodonta & $\mathrm{Nd}$ & nd & 3.28 \\
\hline sg. Aleuritia, sct. Crystallophlomis & & & & sg. Auganthus, sct. Cortusoides & & & & sg. Auriculastrum, sct. Dodecatheon & & & \\
\hline P. chionantha & 5.57 & nd & nd & P. cortusoides & nd & nd & 4.37 & P. austrofrigida & $\mathrm{T}$ & nd & 2.62 \\
\hline P. chionantha ssp. chionantha & 6.35 & nd & nd & P. heucherifolia & $t$ & nd & 2.24 & P. clevelandii & $\mathrm{t}$ & nd & 8.59 \\
\hline P. chionantha ssp. sinopurpurea & 4.31 & nd & nd & P. kisoana & $t$ & nd & 1.68 & P. conjugens & 3.86 & nd & 1.26 \\
\hline P. graminifolia & 1.22 & nd & nd & P. palmata & $t$ & nd & 2.13 & P. jeffreyi & 2.85 & nd & 1.00 \\
\hline P. longipetiolata & 9.48 & nd & nd & P. polyneura & $t$ & nd & 2.22 & P. latiloba & $t$ & nd & 0.77 \\
\hline P. macrophylla & 7.06 & nd & nd & P. sieboldii & $t$ & nd & 4.20 & P. meadia & $\mathrm{t}$ & nd & 3.56 \\
\hline P. orbicularis & 0.60 & nd & nd & sg. Auganthus, sct. Obconicolisteri & & & & P. pauciflora & $\mathrm{t}$ & nd & 5.08 \\
\hline P. purdomii & $\mathrm{t}$ & nd & nd & P. obconica & $t$ & nd & 8.59 & P. tetrandra & $\mathrm{t}$ & nd & 6.90 \\
\hline sg. Aleuritia, sct. Davidii & & & & sg. Auganthus, sct. Reinii & & & & sg. Auriculastrum, sct. Parryi & & & \\
\hline P. bergenioides & 0.73 & nd & nd & P. takedana & $\mathrm{t}$ & nd & 9.09 & P. angustifolia & 0.35 & nd & 8.60 \\
\hline $\begin{array}{l}\text { P. ovaliifolia } \\
\text { sg. Aleuritia, sct. Oreophlomis }\end{array}$ & $t$ & nd & nd & $\begin{array}{l}\text { sg. Auriculastrum, sct. Auricula } \\
\text { P. allionii }\end{array}$ & $\mathrm{t}$ & nd & nd & $\begin{array}{l}\text { P. parryi } \\
\text { P. rusbyi }\end{array}$ & $\begin{array}{c}1.13 \\
\mathrm{t}\end{array}$ & $\begin{array}{l}\text { nd } \\
\text { nd }\end{array}$ & $\begin{array}{l}0.44 \\
0.85\end{array}$ \\
\hline P. auriculata & 3.24 & nd & nd & P. allionii $\times$ P. villosa & $\mathrm{t}$ & nd & nd & sg. Primula, sct. Primula & & & \\
\hline P. luteola & 1.75 & nd & nd & P. auricula & $t$ & nd & nd & P. elatior var. amoena & $t$ & nd & nd \\
\hline P. rosea 'Gigas' & 4.06 & nd & nd & P. carniolica & $\mathrm{t}$ & nd & nd & P. elatior & 3.30 & nd & nd \\
\hline P. warschenewskiana & 5.21 & nd & nd & P. glaucescens ssp. longobarda & $t$ & nd & 0.48 & P. elatior rhiz & 4.63 & nd & nd \\
\hline sg. Aleuritia, sct. Petiolares & & & & P. glutinosa & $t$ & nd & nd & P. juliae & 0.79 & $\mathrm{t}$ & nd \\
\hline P. boothi var. repens & 1.04 & nd & nd & P. hirsuta & $t$ & nd & nd & P. juliae rhiz & 0.21 & $\mathrm{t}$ & nd \\
\hline P. moupinensis & $t$ & nd & nd & P. integrifolia & $t$ & nd & nd & P. megaseifolia & 3.24 & 2.65 & nd \\
\hline P. moupinensis ssp. barkamensis & 1.17 & nd & nd & P. latifolia 'Alba' & $t$ & nd & nd & P. veris (syn. P. officinalis) & 2.84 & $t$ & nd \\
\hline P. sonchifolia ssp. sonchifolia & 0.67 & nd & nd & P. marginata & $t$ & nd & nd & P. vulgaris & 6.23 & 3.26 & nd \\
\hline sg. Aleuritia, sct. Proliferae & & & & P. minima & $t$ & nd & nd & P. vulgaris ${ }^{\text {rhiz }}$ & 3.30 & 2.27 & nd \\
\hline P. besiana & $t$ & nd & nd & P. minima f. niveum & $t$ & nd & nd & sg. Primula, sct. Sredinskya & & & \\
\hline P. japonica 'Alba' & 1.05 & nd & nd & P. tyrolensis & $\mathrm{t}$ & nd & nd & P. grandis (PGRA_K_2014) & 23.88 & nd & nd \\
\hline P. prolifera & $t$ & nd & nd & P. venusta & $t$ & nd & nd & P. grandis (PGRA_K_2016) & 15.72 & nd & nd \\
\hline sg. Aleuritia, sct. Pulchella & & & & & & & & P. grandis rhiz (PGRA_K_2016) & 14.57 & nd & nd \\
\hline P. pulchella & $t$ & nd & $\mathrm{t}$ & & & & & & & & \\
\hline
\end{tabular}


Table A2. Cont.

\begin{tabular}{|c|c|c|c|}
\hline \multirow{2}{*}{ Taxon (d) } & \multicolumn{3}{|c|}{ Average $\%$ of Dry Mass } \\
\hline & PSI & PSII & SSI \\
\hline \multicolumn{4}{|l|}{ sg. Primula, hybrids } \\
\hline $\begin{array}{l}\text { P. margotae } \\
\text { 'GarruardeGuinevere' }\end{array}$ & 4.80 & 0.32 & nd \\
\hline $\begin{array}{l}\text { 'GarryardeGuinevere' } \\
\text { P. margotae rhiz }\end{array}$ & 2.21 & 0.23 & nd \\
\hline \multicolumn{4}{|l|}{ sg. Primula, trade samples } \\
\hline Primulae radix 1 (PR1) & 8.60 & 4.90 & nd \\
\hline Primulae radix 2 (PR2) & 6.16 & $\mathrm{t}$ & nd \\
\hline Primulae radix 3 (PR3) & 2.66 & $\mathrm{t}$ & nd \\
\hline Primulae radix 4 (PR4) & 2.18 & $\mathrm{t}$ & nd \\
\hline \multicolumn{4}{|l|}{ sg. Sphondylia, hybrids } \\
\hline $\begin{array}{l}P . \times \text { kewensis } \\
\text { genus Androsace } \\
\text { sct. Aretia }\end{array}$ & 0.33 & nd & nd \\
\hline A. lehmanii & nd & nd & 1.12 \\
\hline \multicolumn{4}{|l|}{ sct. Chamaejasme } \\
\hline A. adenocephala & nd & nd & $t$ \\
\hline A. brachystegia & nd & nd & $\mathrm{t}$ \\
\hline A. chamaejasme ssp. carinata & nd & nd & \\
\hline A. limprichtii & nd & nd & 0.36 \\
\hline A. robusta ssp. purpurea & nd & nd & 0.76 \\
\hline A. sarmentosa & nd & nd & 1.28 \\
\hline A. strigillosa & $t$ & nd & $\mathrm{t}$ \\
\hline \multicolumn{4}{|l|}{ genus Hottonia } \\
\hline H. inflata $\mathrm{hb}$ & 0.36 & nd & 2.27 \\
\hline H. palustris $\mathrm{hb}$ & 0.31 & nd & 0.62 \\
\hline
\end{tabular}

hb — herb or rhiz — rhizome was used instead of roots; sg.—subgenus, sct.—section, ssp.—subspecies, var.—variety, nd—below LOD, t—between LOQ and $0.2 \%$. Values are averages of triplicates. Standard deviations lower than 5\% in each case. 


\section{References}

1. Richards, J.A. Primula, 2nd ed.; Timber Press: Portland, OR, USA, 2003; ISBN 0-88192-580-2.

2. Halda, J.J. The Genus Primula: In Cultivation and the Wild; Tethys Books: Englewood, CO, USA, 1992; ISBN 0-9632289-0-0.

3. Smith, G.; Lowe, D. The Genus Androsace: A Monograph for Gardeners and Botanists; Alpine Garden Society: Pershore, UK, 1997; ISBN 0-900048-67-0.

4. Grey-Wilson, C. The Genus Dionysia; Alpine Garden Society: Woking, UK, 1989; ISBN 0-900048-51-4.

5. $\mathrm{Hu}, \mathrm{Q}$. On the geographical distribution of the Primulaceae. J. Trop. Subtrop. Bot. 1994, 2, 1-14.

6. Valant-Vetschera, K.M.; Bhutia, T.D.; Wollenweber, E. Exudate flavonoids of Primula spp: Structural and biogenetic chemodiversity. Nat. Prod. Commun. 2009, 4, 365-370. [CrossRef] [PubMed]

7. Müller, A.; Ganzera, M.; Stuppner, H. Analysis of phenolic glycosides and saponins in Primula elatior and Primula veris (primula root) by liquid chromatography, evaporative light scattering detection and mass spectrometry. J. Chromatogr. A 2006, 1112, 218-223. [CrossRef] [PubMed]

8. Colombo, P.S.; Flamini, G.; Rodondi, G.; Giuliani, C.; Santagostini, L.; Fico, G. Phytochemistry of European Primula species. Phytochemistry 2017, 143, 132-144. [CrossRef] [PubMed]

9. EMA Committee on Herbal Medicinal Products (HMPC). Assessment Report on Primula veris L. and/or Primula elatior (L.) Hill, radix. 2012. Available online: https://www.ema.europa.eu/en/documents/herbal-report/finalassessment-report-primula-veris-1/primula-elatior-1-hill-radix_en.pdf (accessed on 19 March 2012).

10. Primrose root (Primulae radix) monograph. In European Pharmacopoeia, 3rd ed.; Council of Europe: Strasbourg, France, 1999; pp. 804-805.

11. Primrose root (Primulae radix) monograph. In European Pharmacopoeia, 10th ed.; Council of Europe: Strasbourg, France, 2020; pp. 1588-1589.

12. Siems, K.; Jaensch, M.; Jakupović, J. Structures of the two saponins isolated from commercially available root extract of Primula sp. Planta Med. 1998, 64, 272-274. [CrossRef] [PubMed]

13. Kitagawa, I.; Yoshikawa, M.; Kobayashi, K.; Imakura, Y.; Im, K.S.; Ikenishi, Y. Saponin and sapogenol. XXVIII. Reinvestigation of the branching positions in the glucuronide moieties of three glucuronide saponins: Desacyl-jegosaponin, deacyl-boninsaponin A and sakuraso-saponin. Chem. Pharm. Bull. (Tokyo) 1980, 28, 296-300. [CrossRef]

14. Kimura, T. Primula sieboldii E. Morren. In International Collation of Traditional and Folk Medicine; Guo, J.-X., Ed.; World Scientific: Singapore, 2001; Volume 4, p. 80.

15. Koczurkiewicz, P.; Kowolik, E.; Podolak, I.; Wnuk, D.; Piska, K.; Łabędź-Masłowska, A.; Wójcik-Pszczoła, K.; Pękala, E.; Czyż, J.; Michalik, M. Synergistic cytotoxic and anti-invasive effects of mitoxantrone and triterpene saponins from Lysimachia ciliata on human prostate cancer cells. Planta Med. 2016, 82, 1546-1552. [CrossRef]

16. Frenkel, N.; Makky, A.; Sudji, I.R.; Wink, M.; Tanaka, M. Mechanistic investigation of interactions between steroidal saponin digitonin and cell membrane models. J. Phys. Chem. B 2014, 118, 14632-14639. [CrossRef]

17. Eid, S.Y.; El-Readi, M.Z.; Wink, M. Synergism of three-drug combinations of sanguinarine and other plant secondary metabolites with digitonin and doxorubicin in multi-drug resistant cancer cells. Phytomedicine 2012, 19, 1288-1297. [CrossRef]

18. Sedaghat Doost, A.; van Camp, J.; Dewettinck, K.; van der Meeren, P. Production of thymol nanoemulsions stabilized using quillaja saponin as a biosurfactant: Antioxidant activity enhancement. Food Chem. 2019, 293, 134-143. [CrossRef]

19. Tschiggerl, C.; Bucar, F. Influence of saponin plants on the volatile fraction of thyme in herbal teas. Fitoterapia 2011, 82, 903-910. [CrossRef] [PubMed]

20. Fleck, J.D.; Betti, A.H.; Da Silva, F.P.; Troian, E.A.; Olivaro, C.; Ferreira, F.; Verza, S.G. Saponins from Quillaja saponaria and Quillaja brasiliensis: Particular chemical characteristics and biological activities. Molecules 2019, 24, 171. [CrossRef]

21. Hegde, V.D.; Silver, J.; Patel, M.G.; Bryant, R.; Pai, J.; Das, P.R.; Puar, M.S.; Cox, P.A. Phospholipase D inhibitors from a Myrsine species. J. Nat. Prod. 1995, 58, 1492-1497. [CrossRef] [PubMed]

22. Vermeersch, M.; Foubert, K.; da Luz, R.I.; Van Puyvelde, L.; Pieters, L.; Cos, P.; Maes, L. Selective antileishmania activity of 13,28-epoxy-oleanane and related triterpene saponins from the plant families Myrsinaceae, Primulaceae, Aceraceae and Icacinaceae. Phyther. Res. 2009, 23, 1404-1410. [CrossRef] [PubMed] 
23. Girardi, C.; Vásquez-Ocmin, P.G.; Castillo, D.; Sauvain, M.; Rojas, R.; Fabre, N.; Haddad, M. Biological activities of 13, 28-epoxyoleanane triterpene saponins from two peruvian Myrsinaceae. Rev. la Soc. Química del Perú 2012, 78, 188-197.

24. Li, Q.; Li, W.; Hui, L.-P.; Zhao, C.-Y.; He, L.; Koike, K. 13,28-Epoxy triterpenoid saponins from Ardisia japonica selectively inhibit proliferation of liver cancer cells without affecting normal liver cells. Bioorg. Med. Chem. Lett. 2012, 22, 6120-6125. [CrossRef]

25. Wang, R.; Xiao, X.; Wang, P.-Y.; Wang, L.; Guan, Q.; Du, C.; Wang, X.-J. Stimulation of autophagic activity in human glioma cells by anti-proliferative ardipusilloside I isolated from Ardisia pusilla. Life Sci. 2014, 110, 15-22. [CrossRef]

26. Cao, W.-Y.; Wang, Y.-N.; Wang, P.-Y.; Lei, W.; Feng, B.; Wang, X.-J. Ardipusilloside-I metabolites from human intestinal bacteria and their antitumor activity. Molecules 2015, 20, 20569-20581. [CrossRef]

27. Mbaveng, A.T.; Ndontsa, B.L.; Kuete, V.; Nguekeu, Y.M.M.; Çelik, İ; Mbouangouere, R.; Tane, P.; Efferth, T. A naturally occuring triterpene saponin ardisiacrispin B displayed cytotoxic effects in multi-factorial drug resistant cancer cells via ferroptotic and apoptotic cell death. Phytomedicine 2018, 43, 78-85. [CrossRef]

28. Patten, A.M.; Vassão, D.G.; Wolcott, M.P.; Davin, L.B.; Lewis, N.G. Trees: A remarkable biochemical bounty. In Comprehensive Natural Products II; Elsevier: Kidlington, UK, 2010; pp. 1173-1296. ISBN 978-0-08-045381-1.

29. Ashihara, H.; Kato, M.; Chuang-Xing, Y. Biosynthesis and metabolism of purine alkaloids in leaves of cocoa tea (Camellia ptilophylla). J. Plant. Res. 1998, 111, 599-604. [CrossRef]

30. Ma, L.; Li, W.; Wang, H.; Kuang, X.; Li, Q.; Wang, Y.; Xie, P.; Koike, K. A simple and rapid method to identify and quantitatively analyze triterpenoid saponins in Ardisia crenata using ultrafast liquid chromatography coupled with electrospray ionization quadrupole mass spectrometry. J. Pharm. Biomed. Anal. 2015, 102, 400-408. [CrossRef] [PubMed]

31. Foam index. In European Pharmacopoeia, 10th ed.; Council of Europe: Strasbourg, France, 2020; p. 317.

32. Włodarczyk, M.; Szumny, A.; Gleńsk, M. Lanostane-Type Saponins from Vitaliana primuliflora. Molecules 2019, 24, 1606. [CrossRef] [PubMed]

33. Kew Herbarium's Digital Collection. Available online: http://apps.kew.org/herbcat/ gotoHerbariumGrowthPage.do (accessed on 28 February 2020).

34. Pauli, G.F.; Jaki, B.U.; Lankin, D.C. Quantitative ${ }^{1} \mathrm{H}$ NMR: Development and potential of a method for natural products analysis. J. Nat. Prod. 2005, 68, 133-149. [CrossRef] [PubMed]

35. Yan, H.-F.; He, C.-H.; Peng, C.-I.; Hu, C.-M.; Hao, G. Circumscription of Primula subgenus Auganthus (Primulaceae) based on chloroplast DNA sequences. J. Syst. Evol. 2010, 48, 123-132. [CrossRef]

36. Mast, A.R.; Reveal, J.L. Transfer of Dodecatheon to Primula (Primulaceae). Brittonia 2007, 59, 79-82. [CrossRef]

37. Bender, S.F.; van der Heijden, M.G.A. Soil biota enhance agricultural sustainability by improving crop yield, nutrient uptake and reducing nitrogen leaching losses. J. Appl. Ecol. 2015, 52, 228-239. [CrossRef]

38. Thirkell, T.J.; Charters, M.D.; Elliott, A.J.; Sait, S.M.; Field, K.J. Are mycorrhizal fungi our sustainable saviours? Considerations for achieving food security. J. Ecol. 2017, 105, 921-929. [CrossRef]

39. Schneeweiss, G.M.; Schönswetter, P.; Kelso, S.; Niklfeld, H. Complex biogeographic patterns in Androsace (Primulaceae) and related genera: Evidence from phylogenetic analyses of nuclear internal transcribed spacer and plastid trnL-F sequences. Syst. Biol. 2004, 53, 856-876. [CrossRef]

40. Mast, A.R.; Kelso, S.; Richards, J.A.; Lang, D.J.; Feller, D.M.S.; Conti, E. Phylogenetic relationships in Primula L. and related genera (Primulaceae) based on noncoding chloroplast DNA. Int. J. Plant Sci. 2001, 162, 1381-1400. [CrossRef]

(C) 2020 by the authors. Licensee MDPI, Basel, Switzerland. This article is an open access article distributed under the terms and conditions of the Creative Commons Attribution (CC BY) license (http://creativecommons.org/licenses/by/4.0/). 